\section{VILNIUS TECH \\ Vilniaus Gedimino technikos universitetas Proceedings of the 24th Conference for Junior Researchers "Science - Future of Lithuania" \\ APLINKOS APSAUGOS INŽINERIJA / ENVIRONMENTAL PROTECTION ENGINEERING}

24-osios Lietuvos jaunujų mokslininkų konferencijos „Mokslas - Lietuvos ateitis“ teminè konferencija

\title{
CIGAREČIŲ IR KAITINAMŲJŲ LAZDELIŲ FILTRŲ ATLIEKŲ SUKELIAMOS TARŠOS TYRIMAI IR VERTINIMAS
}

\author{
Monika Dukštaité ${ }^{1}$, Aušra Zigmontiené ${ }^{2}$ \\ Vilniaus Gedimino technikos universitetas, Aplinkos inžinerijos fakultetas, Aplinkos apsaugos katedra \\ El.p. ${ }^{1}$ dukstaite.monika@gmail.com; ${ }^{2}$ ausra.zigmontiene@vilniustech.lt
}

\begin{abstract}
Anotacija. Pasaulyje kiekvienais metais surūkoma daugiau nei 5,5 trilijonai cigarečių, kurios tam tikru būdu yra šalinamos. Dèl rūkalių ịpročio numesti nuorūką bet kur, šios atliekos yra vienos dažniausiai randamų atliekų aplinkoje visame pasaulyje. Šios atliekos yra ne tik vizuali tarša, bet ir daro rimtą žalą gamtinei aplinkai dèl cigarečių filtruose susikaupusių metalų. Tyrimų tikslas - nustatyti iš cigarečių ir kaitinamujų lazdelių filtrų i aplinką galinčių patekti metalų kiekius. Tyrimo objektai - cigarečių filtrai, kaitinamujų lazdelių filtrai, sunkieji metalai $(\mathrm{Cu}, \mathrm{Mn}, \mathrm{Pb}, \mathrm{Cd}, \mathrm{Cr}, \mathrm{Zn})$. Eksperimentiniai tyrimai atlikti VILNIUS TECH Aplinkos apsaugos ir vandens inžinerijos katedros laboratorijose, vadovaujantis LST EN 12457-4 standartu. Nustatyta, kad iš cigarečiu filtrų daugiausia išsiplove kadmio - 4,577 $\pm 0,018 \mathrm{mg} / \mathrm{kg}$, naudojant distiliuotą vandenị. Cinko, mangano ir chromo daugiausia išsiplovè iš cigarečių naudojant $\mathrm{CaCl}_{2}(\mathrm{pH}=6,1)$ tirpalą, atitinkamai $3,629 \pm 0,016 \mathrm{mg} / \mathrm{kg}, 2,328 \pm 0,005 \mathrm{mg} / \mathrm{kg}$, $0,896 \pm 0,000 \mathrm{mg} / \mathrm{kg}$. Vario ir švino daugiausia išsiplove iš kaitinamųų lazdelių atitinkamai $4,272 \pm 0,012 \mathrm{mg} / \mathrm{kg}$ naudojant distiliuotą vandenị ir $1,329 \pm 0,004 \mathrm{mg} / \mathrm{kg}$ naudojant $\mathrm{CaCl}_{2}$ tirpalą.
\end{abstract}

Reikšminiai žodžiai: cigarečių filtrai, kaitinamųų lazdelių filtrai, cigaretės, kaitinamosios lazdelès, sunkieji metalai, metalų išsiplovimas, $\mathrm{Cu}, \mathrm{Mn}, \mathrm{Pb}, \mathrm{Cd}, \mathrm{Cr}, \mathrm{Zn}$.

\section{Ivadas}

Aplinka suvokiama kaip gamtoje tarpusavyje funkcionuojanti susijusių elementų, tokių kaip žemès paviršiaus ir gelmių, oro, vandens, dirvožemio, floros ir faunos, organinių ir neorganinių medžiagų, žmogaus veiklos sukurtų komponentų visuma, tačiau dèl klestinčios pramonès bei ekonomikos, transporto priemonių plètros, augančio žmonių ir atliekų kiekio šių gamtos komponentų tarša vis didèja. Būtent netinkamas atliekų tvarkymas gali sukelti katastrofiškus padarinius visiems gamtoje funkcionuojantiems elementams, o tai kelia vis didesnị visuomenès ir valdžios institucijų susirūpinimą, todèl atliekų tvarkymo ir su ja susijusios problemos priskiriamos prie svarbiausių ir neatidèliotinai spręstinų problemų. Viena iš tokių atliekųtabako produktų atliekos.

Kiekvienais metais pasaulyje surūkoma daugiau nei 5,5 trilijonai cigarečių, kurių nuorūkos tampa atliekomis ir tam tikru būdu yra šalinamos. Kasmet pasaulyje susidaro apie 1,2 milijonų tonų cigarečių nuorūkų atliekų. Remiantis Amerikos věžio draugijos informacija, manoma, kad šie skaičiai iki 2025 m. padidès daugiau nei 50 \% (Kadir ir
Sarani, 2015). Cigarečių atliekos yra viena iš dažniausiai aptinkamų atliekų miesto vietovèse visame pasaulyje, tai sudaro apie $22-46 \%$ visų randamų atliekų miestuose (Novotny et al., 2009; Roder Green et al., 2014). Taip pat cigarečių atliekos yra antros iš dažniausiai randamų atliekų pakrantėse (Koutela et al., 2020) bei dažniausiai aptinkama atlieka Europos paplūdimiuose (European Commision, 2019). Tai nereiškia, kad šios atliekos šalinamos paplūdimiuose tiesiogiai, tačiau, numetus šias atliekas ant žemès miesto aplinkoje, jos gali patekti ị miesto kanalizacijos vamzdžius, o vèliau $i$ - upelius, upes ir i jūras ar vandenynus (Novony et al., 2009; Koutela et al., 2020). Būtent didžiausia cigarečių nuorūkų problema kyla dèl rūkalių ịpročių numesti nuorūką bet kur - tai lemia šių atliekų kaupimąsi aplinkoje (Rath et al., 2012).

Cigarečių nuorūkos susideda iš tabako liekanų, popieriaus ir filtrų. Nors kiekvienas komponentas kelia skirtingus aplinkosaugos klausimus, tačiau dabartinis dèmesys sutelkiamas i cigarečių filtrų, patekusių i aplinką, negalejjimą biologiškai skaidytis (Barnes, 2011; Novotny et al., 2009; Wallbank et al., 2017). Dèl šios priežasties

(C) 2021 Monika Dukštaitė, Aušra Zigmontienè. Leidèjas Vilniaus Gedimino technikos universitetas. Šis straipsnis yra atvirosios prieigos straipsnis, turintis Kūrybinių bendrijų (Creative Commons) licenciją (CC BY 4.0), kuri leidžia neribotą straipsnio ar jo dalių panaudą su privaloma sąlyga nurodyti autorių ir pirminį šaltinį. 
tabako gaminiu filtrai, kuriuose yra plastiko, buvo priskirti vienkartiniams plastikiniams gaminiams (European Commission, 2019). Tiesa, pastebimai mažiau dèmesio skiriama cigarečių filtruose istrigusiems toksiškiems komponentams bei jų keliamai žalai aplinkai.

Auginant tabaką ir gaminant cigaretes, gali būti naudojama daugiau kaip 4000 skirtingu cheminių junginiu (Slaughter et al., 2011). Kitų mokslininkų teigimu, iš cigarečių dūmų ir atliekų gali išsiskirti daugiau nei 7000 cheminių junginių, iš kurių bent 70 - kancerogeniški (W. Lee ir C. C. Lee, 2015). Būtent cigarečių filtrams patekus ị aplinką, iš filtrų gali išsiplauti toksiški junginiai bei metalai, kurie sukelia neigiamą poveikị aplinkai (Araújo ir Costa, 2019; Booth et al., 2015; W. Lee ir C. C. Lee, 2015; Micevska et al., 2006; Parker ir Rayburn, 2017; Register, 2000; Slaughter et al., 2011; Koutela et al., 2020).

Atsižvelgiant $i$ tai, buvo nustatyta, kad cigarečių filtrai yra labai toksiški įvairioms rūšims, pvz., žuvims (Slaughter et al., 2011), žuvų ir varlių embrionams (W. Lee ir C. C. Lee, 2015; Parker ir Rayburn, 2017), vandens blusoms (Daphnia manga) (Register, 2000), mikrobų ekosistemai jūrų nuosèdose (Quemeneur et al., 2020); jūru bakterijoms (Vibrio fisheri) (Micevska et al., 2006), jūru sliekams Hediste diversicolor (Wright et al., 2015) bei sraigèms (Booth et al., 2015; Gill et al., 2018).

Moksliniuose leidiniuose galima rasti ribotą paskelbtų tyrimų, vertinančių cheminių medžiagų, išsiplaunančių iš cigarečiu filtrų, kiekị (Chevalier et al., 2018; Desideri et al., 2019; Pashapour et al., 2015; Dobaradaran et al., 2016, 2019; Moerman ir Potts, 2011; Hernandez, 2018; Mussalo-Rauhamaa et al., 2010; Moriwaki et al., 2009; Cardoso et al., 2018; Kautela et al., 2020; Pelit et al., 2013). Tirtosios medžiagos dažniausiai buvo metalai (Moerman ir Potts, 2011; Dobaradaran et al., 2016, 2019; Cardoso et al., 2018; Hernandez, 2018; Mussalo-Rauhamaa et al., 2010; Moriwaki et al., 2009; Pelit et al., 2013), tačiau taip pat atlikti radionuklidų (Desideri et al., 2019), nikotino (Roder Green et al., 2014), policiklinių aromatinių angliavandelinių (Dobaradaran et al., 2019) išsiplovimo iš cigarečių filtrų tyrimai.

Moriwaki' is ir jo bendraautoriai (2009) tyre $\mathrm{Cd}, \mathrm{Cu}$, $\mathrm{Pb}, \mathrm{Cr}$ ir As metalu išsiplovimą iš cigarečių filtrų, tačiau eliuate aptiko tik As metalą, kurio koncentracija sieke 0,041 mg/l. Kiti mokslininkai (Moerman ir Potts, 2011) tyrè $\mathrm{Al}, \mathrm{Ba}, \mathrm{Cd}, \mathrm{Cr}, \mathrm{Cu}, \mathrm{Fe}, \mathrm{Mn}, \mathrm{Ni}, \mathrm{Pb}, \mathrm{Sr}$, Ti ir Zn išsiplovimą iš cigarečių filtrų, ivvertindami mirkymo laikotarpio bei $\mathrm{pH}$ priklausomybes. Mokslininkų teigimu, tirpalo $\mathrm{pH}$ neturi lemiamos reikšmès metalų išsiplovimo kiekiui iš cigarečių filtrų (analizuojant natūralių kritulių pH intervalą)
(Moerman ir Potts, 2011; Dobaradaran, 2019), tačiau pastebèta metalu išsiplovimo priklausomybè nuo laiko. Rezultatai rodo, kad kuo ilgiau aplinkoje būna cigarečių filtrų atliekos, tuo labiau šie metalai išsiplauna ị aplinką (Moerman ir Potts, 2011). Dobaradaranas su kolegomis (2016) savo tyrimo metu ịvertino $\mathrm{Cd}, \mathrm{Fe}, \mathrm{As}, \mathrm{Ni}, \mathrm{Cu}, \mathrm{Zn}$ išsiplovimus iš cigarečių filtrų jūrinèje aplinkoje, imdami mèginius iš pakrantès zonos. Autorių teigimu, cigarečiu atliekos - viena iš pakrantès zonos užterštumo metalais priežasčiu (Dobaradaran et al., 2016).

Tačiau dar mažiau tyrimų atlikta vertinant iš kaitinamujjų lazdelių išsiplaunančių metalų kiekius. 2014 m. viduryje buvo pristatytas neužsidegantis tabako gaminys - kaitinamoji lazdelè. Veikimo principas - esant gerokai žemesnei temperatūrai, nei reikia degimui, tabako lazdelè kaitinama specialiai sukurtu laikikliu. Tokio „degimo" metu nesusidaro pelenų ir neišsiskiria stipraus dūmų kvapo, palyginti su ịprastomis cigaretemis. Kaitinamosios lazdelès susideda iš tabako, polimerinès plèvelès filtro, mažo tankio celiuliozès acetato filtro ir tuščiavidurio acetato vamzdelio, skiriančio tabaką nuo polimerinès plèvelès filtro (Smith et al., 2016). Kaitinamosios lazdelès buvo suprojektuotos taip, kad sumažintų kenksmingų cheminių junginių poveikị. Tačiau šiuo metu kaitinamujų lazdelių poveikis įvertintas tik oro kokybei (Mitova et al., 2016; Bekki et al., 2017), o kaitinamujų lazdelių atliekų, patekusių ị aplinką, poveikis nẻra žinomas. Mokslinėse publikacijose aptinkamas tik vienas atliktas tyrimas, kurio metu palygintas metalų ( $\mathrm{Al}, \mathrm{Cr}, \mathrm{Ni}$, $\mathrm{Cu}, \mathrm{Zn}, \mathrm{As}, \mathrm{Se}, \mathrm{Cd}, \mathrm{Ba}, \mathrm{Hg}, \mathrm{Pb}$ ), išsiplaunančių iš kaitinamuju lazdelių, kiekis su metalų išsiplovimu iš ịprastų cigarečių (Kautela et al., 2020). Autorès teigimu, palyginus nerūkytas kaitinamąsias lazdeles su nerūkytomis cigaretemis, didesnès metalo koncentracijos buvo pastebètos iš nerūkytų cigarečių. Priešingi rezultatai pastebimi rūkytose cigaretèse ir rūkytose kaitinamosiose lazdelèse - didesnè išsiplovusių metalų koncentracija pastebima iš kaitinamujų lazdelių. Daroma prielaida, kad taip nutiko dèl sumažejusio cigarečiu svorio - pasišalino pelenai (Kautela et al., 2020). Tačiau tyrimų, vertinančių metalu išsiplovimą iš atskirų kaitinamujų lazdelių dalių, pavyzdžiui, filtru, nèra.

Šiame darbe pateikiamas metalų $(\mathrm{Cu}, \mathrm{Mn}, \mathrm{Pb}, \mathrm{Cd}, \mathrm{Cr}$, Zn) išsiplovimo iš kaitinamųjų lazdelių ir cigarečių filtrų tyrimas. Siekiant ịvertinti metalų išsiplovimo iš filtrų koncentracijas skirtingomis sąlygomis bei palyginti iš kaitinamujų lazdelių ir cigarečių filtrų išsiplaunančių metalų kiekius, eliuatui ruošti naudoti skirtingi tirpalai $-\mathrm{H}_{2} \mathrm{O}$ ir $0,01 \mathrm{M} \mathrm{CaCl}_{2}$ tirpalas. 


\section{Metodika}

Siekiant ištirti metalų, tokių kaip $\mathrm{Cu}, \mathrm{Mn}, \mathrm{Pb}, \mathrm{Cd}, \mathrm{Cr}, \mathrm{Zn}$, galimus patekti į aplinką iš cigarečių filtrų atliekų kiekius, atliekamas metalų išsiplovimo iš cigarečių ir tabako lazdelių filtrų tyrimas. Tyrimas atliekamas vadovaujantis LST EN 12457-4 standartu „Atliekų apibūdinimas. Išplovimas. Iš grūdètų atliekų išplautų medžiagų ir dumblo sudèties atitikties tyrimas. 4 dalis. Vienpakopis partijos (tyrinio) tyrimas, kai skysčio ir kietosios medžiagos, kurios sudètyje yra labai kietų medžiagų, santykis $10 \mathrm{l} / \mathrm{kg}$ ir dalelių dydis mažesnis kaip 10 mm (dydi mažinant arba nemažinant)“.

Šis tyrimas atliekamas siekiant gauti informaciją apie atliekų elgseną jas išplaunant. Iš rūkytų cigarečių ir kaitinamujų lazdelių filtrų išsiplauna didesni kiekiai metalų, lyginant su nerūkytomis (Pashapour et al., 2015; Hernandez, 2018; Koutela et al., 2020). Kadangi būtent tokios atliekos dažniausiai aptinkamos aplinkoje, šio tyrimo metu lyginamos ịprastų rūkytų cigarečių filtruose ir rūkytų tabako lazdelių filtruose esančių cheminių medžiagų koncentracijos.

Tiriant iš cigarečių ir tabako lazdelių filtrų išsiplaunančių metalų kiekius, neatsižvelgiama ị cigarečių ir tabako lazdelių gamintojus. Cigarečių bei tabako lazdelių atliekos iš karto po rūkymo yra surūšiuojamos ir laikomos stikliniuose indeliuose. Vèliau nuo filtrų atskiriami tabako likučiai (1 pav.).

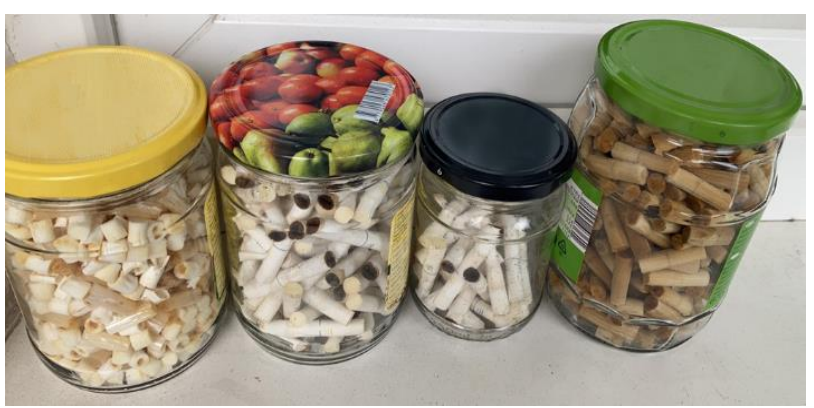

1 paveikslas. Kaitinamụjų lazdelių filtrai, kaitinamųjų lazdelių nuorūkos ir cigarečių filtrai

Siekiant rezultatus gauti artimus natūralioms sąlygoms, atliekos (cigarečių ir kaitinamojo tabako filtrai) nesmulkinamos, nes tokios formos aptinkamos aplinkoje.

Remiantis ISO 11465:1993, nustatoma sausos dalies masè, esant $105 \pm 5^{\circ} \mathrm{C}$ temperatūrai. Sausos ir drègnos masès santykis apskaičiuojamas pagal lygtị:

$$
D R=100 \cdot\left(\frac{M_{D}}{M_{W}}\right),
$$

čia $D R$ - sausosios materijos turinio santykis; $M_{D}$ - sausoji tiriamosios dalies masè, $\mathrm{kg} ; M_{w}-$ neišdžiovintos tiriamosios dalies masè, $\mathrm{kg}$.
Drègmès kiekio santykis (\%) apskaičiuojamas šia lygtimi:

$$
M C=100 \cdot \frac{\left(M_{W}-M_{D}\right)}{M_{D}} .
$$

Eliuatas ruošiamas kambario temperatūroje $\left(20 \pm 5^{\circ} \mathrm{C}\right)$. Pagrindiniai eliuato ruošimo etapai:

- nuo filtrų pašalinami tabako likučiai;

- atliekos pasveriamos ir sumaišomas su distiliuotu vandeniu $(\mathrm{pH}=6,9)$ standarte nustatytu santykiu $\mathrm{L} / \mathrm{S}=10 \mathrm{l} / \mathrm{kg} \pm 2 \%$. Tai reiškia, kad distiliuoto vandens turi būti dešimt kartų daugiau nei paimto sauso mėginio. Mèginio mase $-50 \mathrm{~g}$, distiliuoto vandens $-500 \mathrm{ml}$ (2 pav., a);

- sumaišius atliekas su distiliuotu vandeniu, mėginys įpilamas ị sandarų butelị ir įdedamas ị vertikaluji kratytuvą. Mèginys kratomas 7 val. $\pm 0,5$ val.;

- išèmus mėgini iš vertikalaus kratytuvo, 15 min. \pm 5 min. laukiama, kol nusistovès. Paskui méginys filtruojamas per Vatmano filtrą ir paskui per vakuuminį filtrą su $0,45 \mu \mathrm{m}$ membraniniu filtru;

- išfiltruoti mèginiai parūgštinti $65 \%$ azoto rūgštimi ( $2 \%$ mèginio tūrio).

Antrojo etapo metu vietoj distiliuoto vandens metalams išsiplauti iš filtrų naudojamas $0,01 \mathrm{M} \mathrm{CaCl}_{2}$ tirpalas. Ca yra pagrindinis dirvožemių adsorbcijos komplekso katijonas, todėl $0,01 \mathrm{M} \mathrm{CaCl}_{2}$ yra artimas dirvožemio tirpalui (Houba et al., 2000), taip pat tirpalo $\mathrm{pH}=6,1$, kuris yra artimas aplinkoje aptinkamo lietaus bei dirvožemio $\mathrm{pH}$. Tokiu atveju įvertinamas metalų išsiplovimas artimoms aplinkai sąlygomis.

Tyrimas atliekamas ta pačia tvarka, kaip ir naudojant distiliuotą vandenị. Naudojamo méginio masè $-30 \mathrm{~g}$, 0,01 $\mathrm{M} \mathrm{CaCl}_{2}$ tirpalo - $300 \mathrm{ml}$ (2 pav., b).

Sunkiujų metalų koncentracijos nustatomos taikant atominès absorbcijos spektrinès analizès metodą, naudojant spektrometrą Buck Scientific 210 VGP remiantis standartizuotomis metodikomis. Sunkieji metalai buvo analizuojami naudojant arba liepsnos atominès absorbcijos spektrofotometrą, arba grafito krosnies atominès absorbcijos spektrofotometrą, priklausomai nuo metalų koncentracijos tirpale. Metalų koncentracijos visuose eliuatuose buvo matuojamos 3 kartus. Apskaičiuota vidutinè verte ir standartinis nuokrypis.

Atlikus eliuato analizę, apskaičiuojamos komponentų koncentracijos, esančios eliuatuose, išreikštos mg/l. 


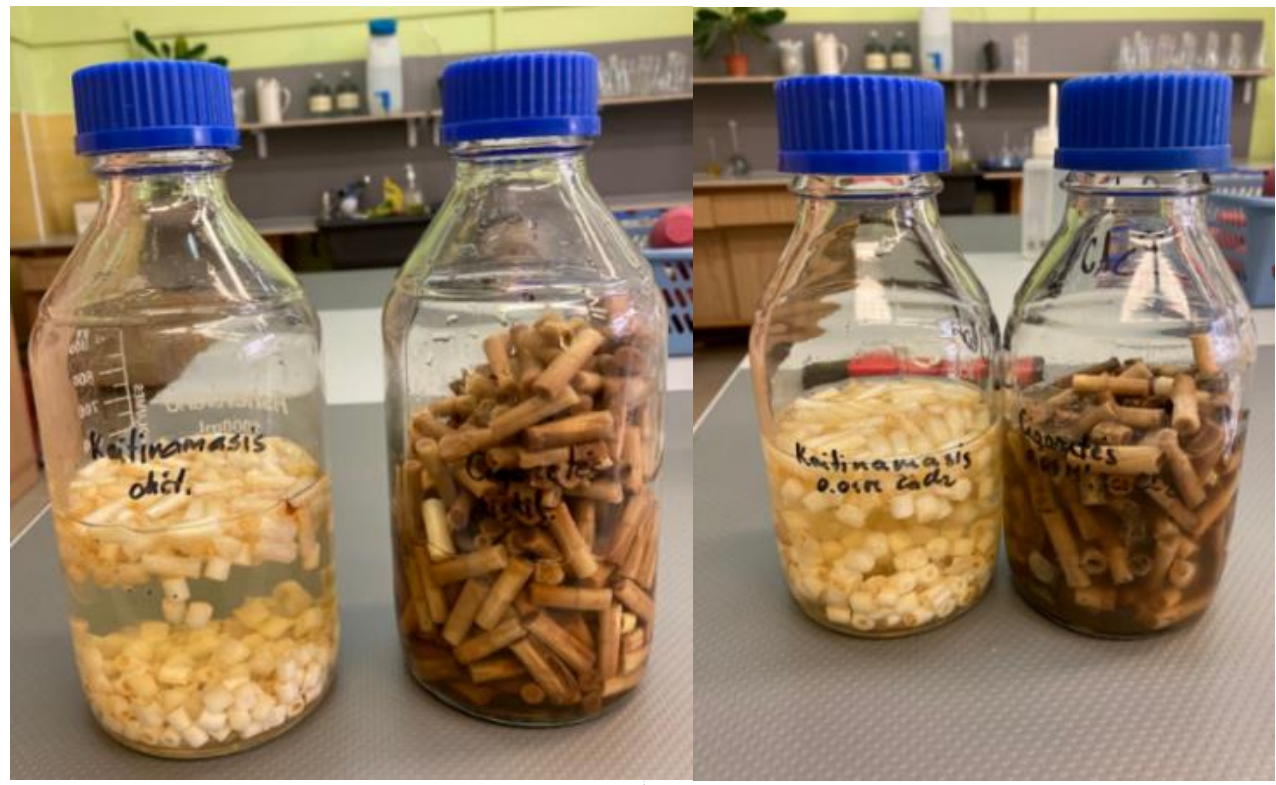

a)

b)

2 paveikslas. Kaitinamųjų lazdelių filtrų ir cigarečių filtrų eliuato paruošimas naudojant: a) $\mathrm{H}_{2} \mathrm{O}$; b) $\mathrm{CaCl}_{2}$ tirpalą

Iš medžiagos išplautos sudedamosios dalies kiekis apskaičiuojamas remiantis pradinès medžiagos sausaja mase pagal šią lygtị:

$$
A=C \cdot\left(\frac{L}{M_{D}}\right)+\frac{M C}{100},
$$

čia $A$ - išsiskyręs sudedamosios dalies kiekis, $\mathrm{mg} / \mathrm{kg}$ sausosios masès; $C$ - tam tikros sudedamosios dalies eliuato koncentracija, $\mathrm{mg} / \mathrm{l} ; L$ - panaudoto išplaunančiojo skysčio tūris, $1 ; M_{D}$ - sausoji tiriamosios dalies masè, $\mathrm{kg} ; M C-$ drègmès kiekio santykis (2 formulè), $\%$.

Ivvertinama, kad vidutinis vienoje cigareteje esančiu filtrų svoris yra $\sim 0,015 \mathrm{~g}$, o kaitinamosiose lazdelèse esančių filtrų svoris $-\sim 0,031 \mathrm{~g}$. Proporcijos principu apskaičiuojama, kokia sunkiujų metalų koncentracija išsiplauna iš 100 vnt. cigarečių filtrų ir kokia sunkiujų metalų koncentracija išsiplauna iš 100 vnt. kaitinamujų lazdelių filtrų.

\section{Rezultatai ir jų analizė}

Vertinant cigarečių ir kaitinamujų lazdelių filtruose esančiu sunkiujų metalu poveikị aplinkai, atliktas išsiplovimo tyrimas, laikantis standarto LST EN 12457-4 reikalavimų. Ištyrus metalų $(\mathrm{Cu}, \mathrm{Mn}, \mathrm{Pb}, \mathrm{Cd}, \mathrm{Cr}, \mathrm{Zn})$ sąveiką su distiliuotu vandeniu ir $0,01 \mathrm{M} \mathrm{CaCl}_{2}$ tirpalu, ivertinta, kiek metalų gali patekti ị aplinką iš cigarečių filtrų ir kaitinamujjų lazdelių filtrų.

Didžiausia mangano išsiplovimo koncentracija $(2,328 \pm 0,005 \mathrm{mg} / \mathrm{kg})$ pastebima cigarečių filtruose, kai išsiplovimo tyrimas buvo atliktas naudojant $0,01 \mathrm{M} \mathrm{CaCl}_{2}$ tirpalą (3 pav.). Iš kaitinamụjų cigarečių tomis pačiomis sąlygomis išsiplovė 3,89 karto mažiau mangano$0,598 \pm 0,001 \mathrm{mg} / \mathrm{kg}$. Mažiausia mangano koncentracija $(0,407 \pm 0,002 \mathrm{mg} / \mathrm{kg})$ pastebima kaitinamujų cigarečių filtruose naudojant distiliuotą vandenị. Tomis pačiomis sąlygomis iš cigarečiu filtrų išsiplove $0,465 \pm 0,002 \mathrm{mg} / \mathrm{kg}$ mangano ( 3 pav.). Mokslinèse publikacijose $\mathrm{Mn}$ išsiplovusio iš cigarečių filtrų koncentracija svyruoja 10,8$123,1 \mathrm{mg} / \mathrm{kg}$ (Moerman ir Potts, 2011; Pelit et al., 2013; Dobaradaran et al., 2019).

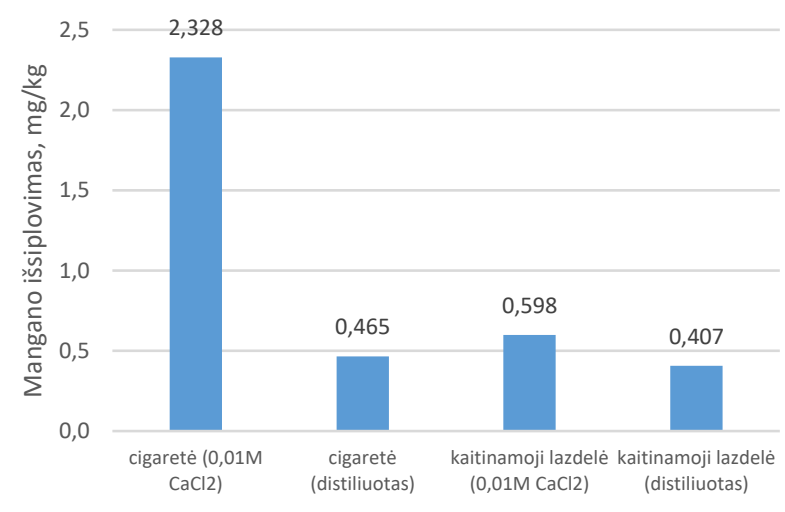

3 paveikslas. Iš kaitinamujų lazdelių ir cigarečių filtrų išsiplovusio Mn koncentracijos, $\mathrm{mg} / \mathrm{kg}$

Cinko išsiplovimo koncentracijos pastebimos didesnès, naudojant $\mathrm{CaCl}_{2}$ tirpalą, lyginant su distiliuotu vandeniu (4 pav.). Iš cigarečių filtrų išsiplovẻ 
$3,629 \pm 0,016 \mathrm{mg} / \mathrm{kg}, \quad$ kaitinamosios lazdelès $1,000 \pm 0,002 \mathrm{mg} / \mathrm{kg}$ cinko naudojant $\mathrm{CaCl}_{2}$ tirpalą. Naudojant distiliuotą vandeni iš cigarečių filtrų išsiplovė 2,73 karto mažiau cinko - $1,328 \pm 0,006 \mathrm{mg} / \mathrm{kg}$, o iš kaitinamosios cigaretės - 0,210 $\pm 0,001 \mathrm{mg} / \mathrm{kg}$ (4 pav.). Mokslinèse publikacijose aptinkamos $\mathrm{Zn}$ išsiplovimo iš cigarečių filtrų koncentracijos svyruoja nuo 4,5 mg/kg iki 217,0 mg/kg (Moerman ir Potts, 2011; Dobaradaran et al., 2019; Mussalo-Rauhamaa et al., 2010; Pelit et al., 2013).

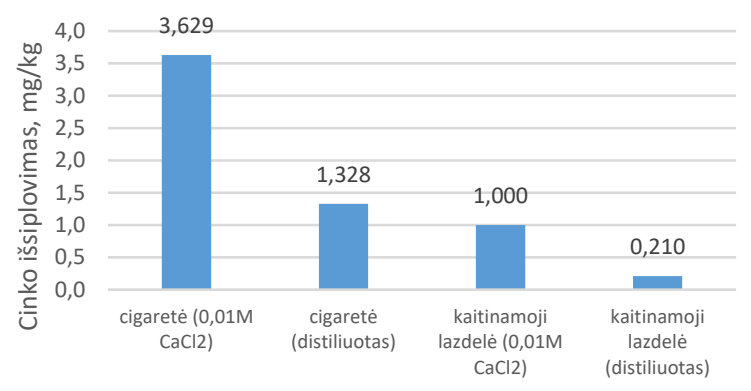

4 paveikslas. Iš kaitinamụjų lazdelių ir cigarečių filtrų išsiplovusio Zn koncentracijos, $\mathrm{mg} / \mathrm{kg}$

Didžiausia švino koncentracija nustatyta naudojant $0,01 \mathrm{M} \mathrm{CaCl}_{2}$ išsiplaunant iš kaitinamujjų lazdelių filtrų, koncentracija siekè 1,329 $\pm 0,004 \mathrm{mg} / \mathrm{kg}$ (5 pav.). Tokiomis pačiomis sąlygomis iš cigarečių filtrų išsiplove $0,928 \pm 0,003 \mathrm{mg} / \mathrm{kg}$ švino. Naudojant distiliuotą vandenị iš cigarečių filtrų išsiplovè $0,866 \pm 0,002 \mathrm{mg} / \mathrm{kg}$, o iš kaitina-

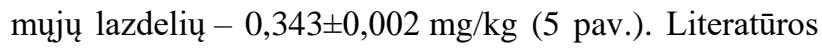
šaltiniuose $\mathrm{Pb}$ išsiplovimas iš cigarečių filtrų siekia $0,8-$ $53,55 \mathrm{mg} / \mathrm{kg}$ (Moerman ir Potts, 2011; Pashapour et al., 2015; Mussalo-Rauhamaa et al., 2010).

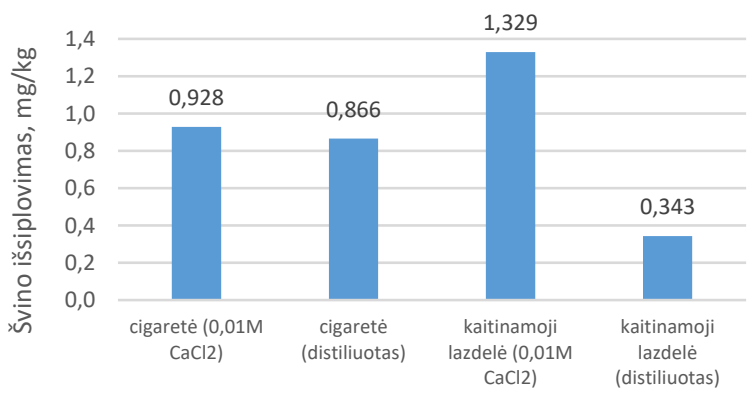

5 paveikslas. Iš kaitinamųjų lazdelių ir cigarečių filtrų išsiplovusio $\mathrm{Pb}$ koncentracijos, $\mathrm{mg} / \mathrm{kg}$

Tiriant chromo išsiplovimą iš filtrų ( 6 pav.), pastebeta, kad didžiausia šio metalo išsiplovimo koncentracija cigarečių filtruose, kai naudojamas $0,01 \mathrm{M} \mathrm{CaCl}_{2}-$
$0,896 \pm 0,000 \mathrm{mg} / \mathrm{kg}$, šiek tiek mažesnè išsiplovimo koncentracija, tokiomis pačiomis sąlygomis pastebèta iš kaiti-

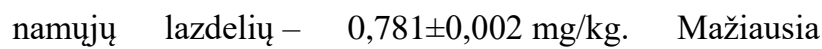
koncentracija pastebima kaitinamųų lazdelių filtrų, naudojant distiliuotą vandeni - 0,031 $\pm 0,002 \mathrm{mg} / \mathrm{kg}$. Moermano ir Pottso (2011) atlikto išsiplovimų iš cigarečių filtrų tyrimo metu $\mathrm{Cr}$ koncentracija siekè $0,48-4,38 \mathrm{mg} / \mathrm{kg}$ (Moerman ir Potts, 2011).

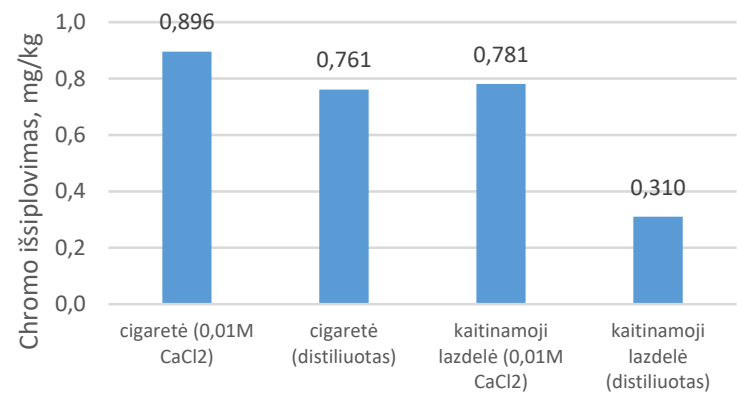

6 paveikslas. Iš kaitinamujų lazdelių ir cigarečių filtrų išsiplovusio $\mathrm{Cr}$ koncentracijos, $\mathrm{mg} / \mathrm{kg}$

Didžiausia kadmio koncentracija išsiplove iš cigarečių filtrų, naudojant distiliuotą vandenị $4,577 \pm 0,018 \mathrm{mg} / \mathrm{kg}, \quad$ naudojant $0,01 \quad \mathrm{M} \quad \mathrm{CaCl}_{2}-$ $2,124 \pm 0,005 \mathrm{mg} / \mathrm{kg}$. Iš kaitinamųjų lazdelių filtrų atitinkamai išsiplovė $0,514 \pm 0,012 \mathrm{mg}, 0,256 \pm 0,004 \mathrm{mg}$ (7 pav.). Mokslinèse publikacijose skelbiama $\mathrm{Cd}$ išsiplovimo iš cigarečių filtrų koncentracija siekia 0,092-5,8 mg/kg (Moerman ir Potts, 2011; Dobaradaran et al., 2019; Pashapour et al., 2015; Mussalo-Rauhamaa et al., 2010; Pelit et al., 2013).

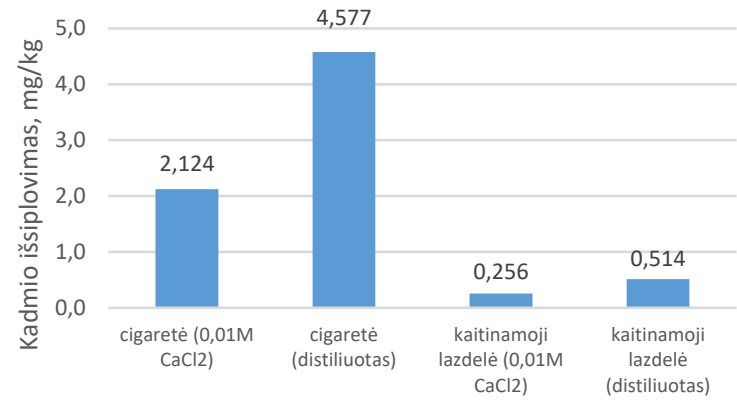

7 paveikslas. Iš kaitinamụjų lazdelių ir cigarečių filtrų išsiplovusio Cd koncentracijos, $\mathrm{mg} / \mathrm{kg}$

Pastebimai didžiausia išsiplovusio vario koncentracija $(4,272 \pm 0,012 \mathrm{mg} / \mathrm{kg})$ užfiksuota iš kaitinamosios lazdelès filtrų, naudojant distiliuotą vandenị (8 pav.). 
Tokiomis pat sąlygomis iš cigaretès išsiplove $0,539 \pm 0,002 \mathrm{mg} / \mathrm{kg}$ vario (mažiausia koncentracija) (8 pav.). Moksliniuose šaltiniuose $\mathrm{Cu}$ koncentracija varijuoja nuo 0,48 mg/kg iki 65,7 mg/kg (Moerman ir Potts, 2011; Pelit et al., 2013; Dobaradaran et al., 2019; MussaloRauhamaa et al., 2010).

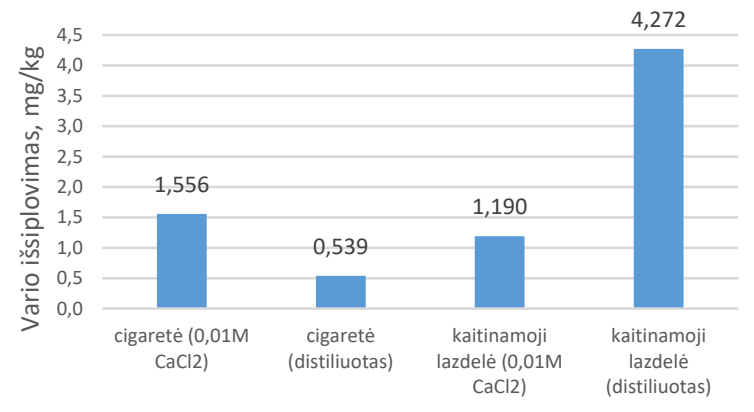

8 paveikslas. Iš kaitinamujų lazdelių ir cigarečių filtrų išsiplovusio $\mathrm{Cu}$ koncentracijos, $\mathrm{mg} / \mathrm{kg}$

Tyrimo metu gautų metalų išsiplovimo koncentracijų skirtumą tarp mokslinėse publikacijose aptinkamų verčių galèjo lemti skirtingos taikytos metodikos. Šio tyrimo metu nebuvo vertinta metalų išsiplovimo priklausomybe nuo laiko. Taip pat neatsižvelgta ì cigarečių gamintojus. Be kita ko, svarbu pabrèžti, kad eliuatui ruošti naudotos aplinkai artimos sąlygos - nevertinti metalų išsiplovimai smarkiai rūgštinèje aplinkoje (Moerman ir Potts, 2011; Pelit et al., 2013; Dobaradaran et al., 2019; Mussalo-Rauhamaa et al., 2010; Pashapour et al., 2015).

Didesnès metalų koncentracijos, tokių kaip $\mathrm{Cr}, \mathrm{Pb}$, $\mathrm{Mn}, \mathrm{Zn}$ bei $\mathrm{Cu}$ (iš cigarečių filtrų), nustatytos eliuatuose, kuriems ruošti buvo naudotas $0,01 \mathrm{M}$ tirpalas, lyginant su $\mathrm{H}_{2} \mathrm{O}$ (3-6 pav., 8 pav.). Tik $\mathrm{Cu}$ (iš kaitinamųu lazdelių) ir $\mathrm{Cd}$ didesni išsiplovimai aptinkami eliuatuose, kuriems ruošti buvo naudotas $\mathrm{H}_{2} \mathrm{O}$, lyginant su $0,01 \mathrm{M}$ tirpalu (78 pav.) Atsižvelgiant ị kitų mokslininkų darbuose pateiktas išvadas, kad metalų išsiplovimui iš filtrų neturi įtakos eliuatui ruošti naudoto tirpalo pH (Moerman ir Potts, 2011; Kautela et al., 2020), daroma prielaida, kad metalų mobilumui bei išsiplovimui iš kaitinamųjų lazdelių bei cigarečių filtrų turi eliuatui ruošti naudojami tirpalai, jų sudètis, o ne $\mathrm{pH}$.

Naudojant 0,01 $\mathrm{M} \mathrm{CaCl}_{2}$ eliuatui ruošti, gaunamos didesnès metalų ( $\mathrm{Mn}, \mathrm{Cu}, \mathrm{Pb}, \mathrm{Zn}$ ) koncentracijos, lyginant su $\mathrm{H}_{2} \mathrm{O}$ (3-6 pav., 8 pav.) (Bakircioglu et al., 2011). $0,01 \mathrm{M} \mathrm{CaCl}_{2}$ tirpalas yra geresnis išploviklis nei distiliuotas vanduo. Taip pat, kadangi 0,01 M tirpalo yra žemesni
$\mathrm{pH}$, lyginant su $\mathrm{H}_{2} \mathrm{O}$, tirpalas gali lengviau išplauti silpnai adsorbuotus elementus, tokius kaip Zn (Lov et al., 2019). Taip pat $\mathrm{Cu}, \mathrm{Pb}$ - labai jautrūs kompleksavimo procesams, todèl tiriant jų mobilumą ir išsiplovimus, naudojant skirtingas metodikas, gali būti pastebimi dideli koncentracijų skirtumai (5 pav., 8 pav.) (van der Sloot et al., 1997; Sahuquillo et al., 2002). Analizuojant Cd išsiplovimą, pastebèta, kad šis metalas druskingoje aplinkoje mažiau judrus nei bedruskejje aplinkoje (7 pav.) (Bell et al., 1991; Li ir Shuman, 1997).

Atsižvelgiant $\mathfrak{i}$ tai, kad cigaretėse ir kaitinamosiose lazdelèse naudojamų filtrų svoriai skiriasi, ịvertinamas iš 100 vienetų filtrų išsiplovusių metalų kiekis (9 pav.)

Daugiausia tiriamųjų metalų išsiplovė iš kaitinamųu lazdelių naudojant distiliuotą vandenị $0,185 \pm 0,001 \mathrm{mg} / 100$ vnt. filtrų. Didžiąją tiriamųjų išsiplovusių metalų dali sudaro $\mathrm{Cu}-70,7 \%, \mathrm{Cd}$ sudaro $8,5 \%$, $\mathrm{Mn}-6,7 \%, \mathrm{~Pb}-5,7 \%, \mathrm{Cr}-5,0 \%$, o $\mathrm{Zn}-3,4 \%$ visu išsiplovusių tiriamųjų metalų iš kaitinamųjų lazdelių filtrų, naudojant distiliuotą vandeni, dalį.

Mažiausiai tiriamujuc metalų išsiplovè iš cigarečių naudojant distiliuotą vandenị - 0,124 $\pm 0,000 \mathrm{mg} / 100 \mathrm{vnt}$. filtrų. Didžiausiąą tiriamujų išsiplovusių metalų dalị sudaro Cd 53,6 \%, mažiausią Mn - 5,4 \%. Zn sudaro 15,6\%, $\mathrm{Pb}-10,2 \%, \mathrm{Cr}-8,9 \%, \mathrm{Cu}-6,3 \%$ visu išsiplovusių tiriamujų metalų iš cigarečių filtrų, naudojant distiliuotą vandenị, dalị.

Iš cigarečių filtrų, naudojant $\mathrm{CaCl}_{2}$, iš viso išsiplovè $0,167 \pm 0,001 \mathrm{mg} / 100$ vnt. filtru tiriamujų metalų. Zn sudare $31,7 \%, \mathrm{Mn}-20,3 \%, \mathrm{Cd}-18,5 \%, \mathrm{Cu}-13,6 \%, \mathrm{~Pb}-$ $8,1 \%, \mathrm{Cr}-7,8 \%$, visų išsiplovusių tiriamųų metalų iš cigarečių filtrų, naudojant $0,01 \mathrm{M} \mathrm{CaCl}_{2}$, dalị.

Iš kaitinamujų lazdelių filtrų naudojant $\mathrm{CaCl}_{2}$ iš viso išsiplovė $0,158 \pm 0,001 \mathrm{mg} / 100 \mathrm{vnt}$. filtrų tiriamųjų metalų. $\mathrm{Pb}$ sudare $25,7 \%, \mathrm{Cu}-23,1 \%, \mathrm{Zn}-19,4 \%, \mathrm{Cr}-15,2 \%$, $\mathrm{Mn}-11,6 \%, \mathrm{Cd}-5,0 \%$.

Iš 9 paveikslo matome, kad artimomis natūraliai aplinkai sąlygomis $\left(0,01 \mathrm{M} \mathrm{CaCl}_{2}\right)$ daugiau tirtų metalų $(\mathrm{Pb}$, $\mathrm{Zn}, \mathrm{Mn}, \mathrm{Cr}, \mathrm{Cd}, \mathrm{Cu}$ ) išsiplaus iš cigarečių filtrų, lyginant su kaitinamosiomis cigaretėmis, analizuojant tą patị filtrų vienetų skaičių. Lyginant (9 pav.) metalų išsiplovimus naudojant distiliuotą vandenic, nustatyta, kad daugiausia metalų išsiplaus iš kaitinamųjų lazdelių filtrų, analizuojant tą patị vienetų skaičių. Svarbu pabrèžti, kad didžiausią tirtụjų metalų dalị (kaitinamųjų lazdelių atveju naudojant $\mathrm{H}_{2} \mathrm{O}$ ) sudarè $\mathrm{Cu}$. Kaip ir buvo minèta, $\mathrm{Cu}$ dèl kompleksavimo procesu gali pasiekti koncentracijas, kurios gerokai viršija pusiausvyros vertes 


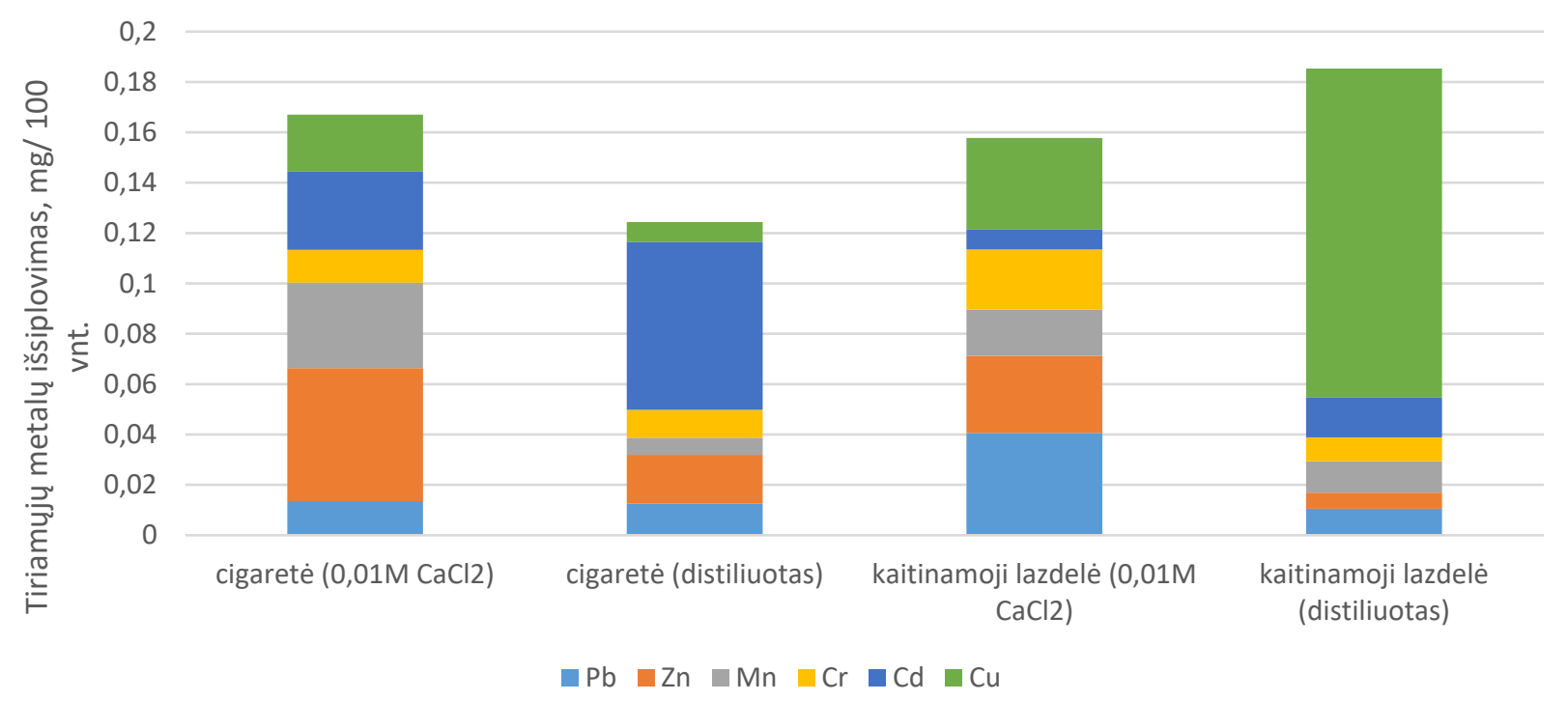

9 paveikslas. Iš kaitinamujų lazdelių ir cigarečių filtrų išsiplovusių $\mathrm{Pb}, \mathrm{Zn}, \mathrm{Mn}, \mathrm{Cr}, \mathrm{Cd}, \mathrm{Cu}$ metalų koncentracijos, vertinant 100 vnt. filtrų

(van der Sloot et al., 1997; Sahuquillo et al., 2002). Norint ìvertinti $\mathrm{Cu}$ išsiplovimą iš kaitinamųjų lazdelių, reikalingi išsamūs moksliniai tyrimai. Tuo atveju, jei nevertinama išsiplovusio $\mathrm{Cu}$ koncentracijos (visais atvejais), daugiausia metalų išsiplove iš cigarečių $\left(0,01 \mathrm{M} \mathrm{CaCl}_{2}\right)$. Pastebima tendencija, kad didesnès išsiplovusių metalų vertès gautos esant artimoms aplinkai sąlygoms - naudojant $0,01 \mathrm{M} \mathrm{CaCl}_{2}$.

\section{Išvados}

1. Iš cigarečių filtrų išsiplovė didesnis metalų (Mn, Zn, Cd, Cr) kiekis, lyginant su kaitinamujų cigarečių filtrais, tokiomis pačiomis sąlygomis.

2. Iš cigarečių ir kaitinamųjų lazdelių filtrų išsiplovusių metalų kiekis priklauso nuo eliuatui ruošti naudojamo tirpalo. Iš cigarečių ir kaitinamujų lazdelių filtrų išsiplovusių metalų ( $\mathrm{Pb}, \mathrm{Zn}, \mathrm{Mn}, \mathrm{Cr})$ didesnès koncentracijos nustatytos naudojant $\mathrm{CaCl}_{2}$ tirpalą, lyginant su $\mathrm{H}_{2} \mathrm{O}$. 0,01 M $\mathrm{CaCl}_{2}$ tirpalas yra geresnis $\mathrm{Pb}, \mathrm{Zn}, \mathrm{Mn}, \mathrm{Cr}$ metalų išploviklis nei distiliuotas vanduo.

3. $\mathrm{Cu}$ ir $\mathrm{Pb}$ gautos nestabilios vertès. Nustatyta, kad iš kaitinamųjų lazdelių filtrų naudojant $0,01 \mathrm{M} \mathrm{CaCl}_{2}$ tirpalą išsiplovė didesnis $\mathrm{Pb}$ kiekis, lyginant su cigarečių filtrais, tačiau, naudojant $\mathrm{H}_{2} \mathrm{O}$, didesnès išsiplovusio $\mathrm{Pb}$ vertès nustatytos iš cigarečių filtrų. $\mathrm{Cu}$ didesnè koncentracija nustatyta vertinant kaitinamųjų lazdelių filtrus naudojant $\mathrm{H}_{2} \mathrm{O}$, o naudojant $0,01 \mathrm{CaCl}_{2}$ tirpalą didesnè išsiplovusio $\mathrm{Cu}$ koncentracija pastebèta iš cigarečių filtrų.
Tokius rezultatus galèjo lemti tai, $\mathrm{kad} \mathrm{Cu}$ ir $\mathrm{Pb}$ yra jautrūs kompleksavimo procesams, todèl analizuojant jų mobilumą, gali būti pastebimi dideli koncentracijų skirtumai.

4. Cd atveju didesnès koncentracijos nustatytos naudojant $\mathrm{H}_{2} \mathrm{O}$. Atsižvelgiant $i \mathfrak{i}$ analizuotus mokslinius tyrimus, daroma prielaida, kad tokius rezultatus lèmé tai, jog Cd didesnis mobilumas pastebimas bedruskèje aplinkoje.

5. Didžiausias tirtų metalų ( $\mathrm{Pb}, \mathrm{Zn}, \mathrm{Mn}, \mathrm{Cr}, \mathrm{Cd}, \mathrm{Cu})$ kiekis išsiplovė iš kaitinamujų lazdelių naudojant distiliuotą vandenį. Tačiau pusė šio kiekio sudarė $\mathrm{Cu}$. Tokią $\mathrm{Cu}$ vertę galejo lemti $\mathrm{Cu}$ jautrumas kompleksavimo procesams. Neatsižvelgiant ị $\mathrm{Cu}$ koncentracijas (visais atvejais), daugiausia metalų išsiplove iš cigarečių filtrų naudojant $\mathrm{CaCl}_{2}$ tirpalą.

6. Norint visiškai suprasti metalų, išsiplaunančių iš kaitinamųjų lazdelių ir cigarečių filtrų, elgesị ir ịvertinti poveikị aplinkai, būtini platesni išsiplaunančių iš kaitinamujų lazdelių ir cigarečių filtrų metalų tyrimai.

7. Siekiant sumažinti cigarečių ir kaitinamujjų lazdelių atliekų kaupimąsi aplinkoje bei jų sukeliamą neigiamą poveikị aplinkai, būtina imtis atitinkamų priemonių. Vienas pagrindinių veiksnių, norint sumažinti aplinkos taršą šiomis atliekomis, yra švietimas. Taip pat būtina taikyti gamintojų atsakomybès principą cigarečių ir kaitinamųjų lazdelių filtrams, sukurti mokesčių sistemą ir taikyti baudžiamają atsakomybę už netinkamą atliekų šalinimą bei tvarkymą. Be to, labai svarbu nagrinèti šių pavojingų atliekų perdirbimo galimybes. 


\section{Literatūra}

Araújo, M. C. B., \& Costa, M. F. (2019). A criticla reviewof the issue of cigarette butt pollution in coastal environments. Environmental Research, 172, 137-149.

https://doi.org/10.1016/j.envres.2019.02.005

Bakircioglu, D., Bakircioglu Kurtulus, Y., \& Ibar, H. (2011). Comparison of extraction procedures for assessing soil metal bioavailability of to wheat grains. Clean - Soil, Air, Water, 39(8), 728-734. https://doi.org/10.1002/clen.201000501

Barnes, R. L. (2011). Regulating the disposal of cigarette butts as toxic hazardous waste. Tobacco Control, 20, 45-48. https://doi.org/10.1136/tc.2010.041301

Bekki, K., Inaba, Y., Uchiyama, S., \& Kunugita, N. (2017). Comparison of chemicals in mainstream smoke in heat-not-burn tobacco and combustion cigarettes. Journal of UOEH, 39(3), 201-207. https://doi.org/10.7888/juoeh.39.201

Bell, P. F., James, B. R., \& Chancy, R. L. (1991). Heavy metal extractability in long-term sewage sludge and metal saltamended soils. Journal of Environmental Quality, 20, 481486.

https://doi.org/10.2134/jeq1991.00472425002000020023x

Booth, D. J., Gribben, P., \& Parkinson, K. (2015). Impact of cigarette butt leachate on tidepool snails. Marine Pollution Bulletin, 95, 362-364. https://doi.org/10.1016/j.marpolbul.2015.04.004

Cardoso, L. S., Estrela, F. N., Chagas, T. Q., da Silva, W. A. M., de Oliveira Costa, D. R., Pereira, I., Vaz, B. G., de Lima Rodrigues, A. S., \& Malafaia, G. (2018). The exposure towaterwith cigarette residue changes the anti-predator response in female Swiss albino mice. Environmental Science and Pollution Research, 25, 8592-8607.

https://doi.org/10.1007/s11356-017-1150-4

Chevalier, Q., Hadri, H. E., Petitjean, P., Bouhnik-Le Coz, M., Reynaud, S., Grassl, B., \& Gigault, J. (2018). Nano-litter from cigarette butts: Environmental implications and urgent consideration. Chemosphere, 194, 125-130. https://doi.org/10.1016/j.chemosphere.2017.11.158

Desideri, D., Meli, M. A., \& Roselli, C. (2019). Leaching tests to assess the release of 210 Po from discarded cigarette butts. Microchemical Journal, 145, 42-46.

https://doi.org/10.1016/j.microc.2018.10.008

Dobaradaran, S., Nabipour, I., Saeedi, R., Ostovar, A., Khorsand, M., Khajeahmadi, N., Hayati, R., \& Keshtkar, M. (2016). Association of metals (Cd, Fe, As, Ni, $\mathrm{Cu}, \mathrm{Zn}$ and $\mathrm{Mn}$ ) with cigarette butts in northern part of the Persian Gulf. Tobacco Control, 1-3.

https://doi.org/10.1136/tobaccocontrol-2016-052931

Dobaradaran, S., Schimidt, T., Lorenzo-Parodi, N., \& Jochmann, M. (2019). Cigarette butts: An overlooked source of PAHs in the environment? Environmental Pollution, 249, 932-939. https://doi.org/10.1016/j.envpol.2019.03.097

European Commission. (2019). Directive (EU) 2019/904 of the European Parliament and the Council of 5 June 2019 on the reduction of the impact of certain plastic products on the environment. Official Journal of the European Union, 155, 119.

Gill, H., Rogers, K. J., Rehman, B., \& Moynihan, J. (2018). Cigarette butts may have low toxicity to soil-dwelling invertebrates: Evidence from a land snail. Science of the Total Environment, 628-629, 556-561.

https://doi.org/10.1016/j.scitotenv.2018.02.080
Hernandez, C. G. (2018). Cigarette litter leachates: a statistical study of elements in freshwater and saltwater. UTC Scholar, $12,1-39$.

Houba, V. J. G., Temminghoff, E. J. M., Gaikhorst, G. A., \& van Vark, W. (2000). Soil analysis procedures using 0.01 M calcium chloride as extraction reagent. Communications in Soil Science and Plant Analysis, 31, 1299-1396.

https://doi.org/10.1080/00103620009370514

International Organization for Standardization. (n.d.). ISO 11465-1993: Soil quality - Determination of dry matter and water content on a mass basis - Gravimetric method [Qualité du sol - Détermination de la teneur en matiére séche et an eau pondérale - Méthode gravimétrique].

https://www.iso.org/standard/20886.html

Kadir, A., \& Sarani, N. (2015). Cigarette butts pollution and environmental impact - a review. Applied Mechanics and Materials, 773-774, 1106-1110.

https://doi.org/10.4028/www.scientific.net/AMM.773774.1106

Koutela, N., Fernandez, E., Suru, M. L., \& Psillakis, E. (2020). A comprehensive study on the leaching of metals from heated tabacco sticks and cigarettes in water and natural waters. Science of the Total Environment, 714, 1-11. https://doi.org/10.1016/j.scitotenv.2020.136700

Lee, W., \& Lee, C. C. (2015). Developmental toxicity of cigarette butts - An underdeveloped issue. Ecotoxicology and Environmental Safety, 113, 362-368. https://doi.org/10.1016/j.ecoenv.2014.12.018

Li, Z., \& Shuman, M. L. (1997). Mobility of $\mathrm{Zn}, \mathrm{Cd}$ and $\mathrm{Pb}$ in soils as affected by poultry litter extract-II. Redistribution among soil fractions. Environmental Pollution, 95(2), 227234. https://doi.org/10.1016/S0269-7491(96)00074-7

Lietuvos standartizacijos departamentas. (2003). LST EN 124574:2003. Atlieku apibūdinimas. Išplovimas. Iš grūdètu atlieku išplautu medžiagu ir dumblo sudeties atitikties tyrimas. 4 dalis. Vienpakopis partijos (tyrinio) tyrimas, kai skysčio ir kietosios medžiagos, kurios sudètyje yra labai kietu medžiagu, santykis $10 \mathrm{l} / \mathrm{kg}$ ir daleliu dydis mažesnis kaip $10 \mathrm{~mm}$ (dydi mažinant arba nemažinant) [Characterisation of waste - Leaching - Compliance test for leaching of granulal waste materials and sludges - Part 4: One stage batch test at a liquid to solid ratio of $10 \mathrm{l} / \mathrm{kg}$ for materials with particle size below 10 $\mathrm{mm}$ (without or with size reduction)]. Vilnius.

Lov, A., Larsbo, M., Sjostedt, C., Cornelis, G., \& Gustafsson, J. P. (2019). Evaluating the ability of standardised leaching tests to predict metal(loid) leaching from intact soil columns using size-based elemental fractionation. Chemosphere, 222, 453-460. https://doi.org/10.1016/j.chemosphere.2019.01.148

Micevska, T., Warne, M. S. J., Pablo, F., \& Patra, R. (2006). Variation in, and causes of, toxicity of cigarette butts to a cladoceran and microtox. Arcives of Environmental Contamination and Toxicology, 50(2), 205-212. https://doi.org/10.1007/s00244-004-0132-y

Mitova, M. I., Campelos, P. B., Goujon-Ginglinger, C. G., Maeder, S., Mottier, N., Rouget, E. G. R. R., Tharin, M., \& Tricker, A. R. (2016). Comparison of the impact of the Tobacco Heating System 2.2 and a cigarette on indoor air quality. Regulatory Toxicology and Pharmacology, 80, 91-101. https://doi.org/10.1016/j.yrtph.2016.06.005

Moerman, J. W., \& Potts, G. E. (2011). Analysis of metals leached from smoked cigarette litter. Tobacco Control, 20, 3035. https://doi.org/10.1136/tc.2010.040196 
Moriwaki, H., Kitajima, S., \& Katahira, K. (2009). Waste on the roadside, "poi-sute" waste: its distribution and elution potential of pollutants into environment. Waste Management, 29, 1192-1197.

https://doi.org/10.1016/j.wasman.2008.08.017

Mussalo-Rauhamaa, H., Salmela, S. S., Leppänen, A., \& Pyysalo, H. (2010). Cigarettes as a source of same trace and heavy metals and pesticides in man. Archives of Environmental Health: An International Journal, 41(1), 49-55. https://doi.org/10.1080/00039896.1986.9935765

Novotny, T., Lum, K., Smith, E., Wang, V., \& Barnes, R. (2009). Cigarettes butts and the case for an environmental policy on hazardous cigarette waste. International Journal of Environmental Research and Public Health, 6, 1691-1705. https://doi.org/10.3390/ijerph6051691

Parker, T. T., \& Rayburn, J. (2017). A comparison of electronic and traditional cigarette butt leachate on the development of Xenopus laevis embryos. Toxicology Reports, 4, 77-82. https://doi.org/10.1016/j.toxrep.2017.01.003

Pashapour, S., Mousavi, Z., Ziarati, P., \& Ebrahim Najafabadi, K. (2015). Comparison of the level of cadmium and lead between the cigarette filters of different Iranian and nonIranian brands. Journal of Toxicology, 9(29), 1296-1300.

Pelit, F. O., Demirdogen, R. E., \& Henden, E. (2013). Investigation of heavy metal content of Turkish tobacco leaves, cigarette butt, ash, and smoke. Environmental Monitoring and Assessment, 185, 9471-9479. https://doi.org/10.1007/s10661-013-3266-4

Quemeneur, M., Chifflet, S., Akrout, F., Bellaaj-Zouari, A., \& Belhassen, M. (2020). Impact of cigarette butts on microbial diversity and dissolved trace metals in coastal marine sediment. Estuarine Coastal and Shelf Science, 240(2), 1-8. https://doi.org/10.1016/j.ecss.2020.106785

Rath, J. M., Rubenstein, R. A., Curry, L. E., Shank, S. E., \& Cartwright, J. C. (2012). Cigarette litter: smokers' attitudes and behaviors. International Journal of Environmental Research and Public Health, 9(6), 2189-2203. https://doi.org/10.3390/ijerph9062189

Register, K. (2000). Cigarette butts as litter- toxic as well as ugly? Underwater Naturalist, 25, 23-29.

Roder Green, A. L., Putschew, A., \& Nehls, T. (2014). Littered cigarette butts as a source of nicotine in urban waters. Journal of Hydrology, 519, 3466-3474. https://doi.org/10.1016/j.jhydrol.2014.05.046

Sahuquillo, A., Rigol, A., \& Rauret, G. (2002). Comparison of leaching tests for the study of trace metals remobilisation in soils and sediments. Journal of Environmental Monitoring, 4(6), 1003-1009. https://doi.org/10.1039/b206284b

Slaughter, E., Gersberg, R. M., Watanabe, K., Rudolph, J., Stransky, C., \& Novotny, T. E. (2011). Toxicity of cigarette butts, and their chemicalcomponents, to marine and freshwater fish. Tabacco Control, 20, 25-29. https://doi.org/10.1136/tc.2010.040170

Smith, M. R., Clark, B., Lüdicke, F., Schaller, J. P., Vanscheeuwijck, P., Hoeng, J., \& Peitsch, M. C. (2016). Evaluation of the Tobacco Heating System 2.2. Part 1: description of the system and the scientific assessment program. Regulatory Toxicology and Pharmacology, 81, 17-26. https://doi.org/10.1016/j.yrtph.2016.07.006

van der Sloot, H. A., Heasman, L., \& Quevauviller, P. (1997). Harmonization of leaching/extraction tests. Elsevier.

Wallbank, L. A., MacKenzie, R., \& Beggs, P. J. (2017). Environmtal impacts of tobacco product waste: international and Australian policy responses. A Journal of the Human Environment, 46(3), 361-370. https://doi.org/10.1007/s13280-016-0851-0

Wright, L. S., Rowe, D., Reid, J. M., Thomas, K. V., \& Galloway, S. T. (2015). Bioaccumulation and biological effects of cigarette litter in marine worms. Scientific Reports, 5, 14119. https://doi.org/10.1038/srep14119

\section{RESEARCH OF THE ENVIRONMENTAL IMPACT OF OF CIGARETTE AND TOBACCO STICK FILTERS}

M. Dukštaitè, A. Zigmontienè

Summary

Every year, more than 5.5 trillion cigarettes are smoked worldwide, which are disposed of in some way. Due to the smoker's habit of "dropping the cigarette butt everywhere" - this refuse is one of the most commonly found wastes in the environment worldwide. This waste is not only a visual pollution, but it also causes serious damage to the environment due to the metals accumulated in cigarette filters. The objective of this research is to determine the amount of metals that could be released into the environment from cigarette and heat stick filters. The materials of the research include cigarette filters, heat stick filters and heavy metals $(\mathrm{Cu}, \mathrm{Mn}, \mathrm{Pb}, \mathrm{Cd}, \mathrm{Cr}, \mathrm{Zn})$. The experimental research has been performed in the laboratories of the Department of Environmental Protection and Water Management Engineering of the Vilnius Tech in accordance with LST EN 12457-4 standard. As the research has shown, the most leached metal from cigarette filters was cadmium - with $4.577 \pm 0.018 \mathrm{mg} / \mathrm{kg}$ of cadmium being leached using distilled water. Zinc, manganese and chromium were mainly leached from cigarette filters using $\mathrm{CaCl}_{2}(\mathrm{pH}=6.1)-3.629 \pm 0.016 \mathrm{mg} / \mathrm{kg} ; 2.328 \pm 0.005 \mathrm{mg} / \mathrm{kg}$; $0.896 \pm 0.000 \mathrm{mg} / \mathrm{kg}$ respectively. Copper and lead were mostly leached from the heat sticks filters $-4.272 \pm 0.012 \mathrm{mg} / \mathrm{kg}$ of copper leached using distillated water; and $1.329 \pm 0.004 \mathrm{mg} / \mathrm{kg}$ lead using $\mathrm{CaCl}_{2}$ solution.

Keywords: cigarette filters, heat stick filters, cigarette, heat stick, heavy metals, leaching metals, $\mathrm{Cu}, \mathrm{Mn}, \mathrm{Pb}, \mathrm{Cd}, \mathrm{Cr}, \mathrm{Zn}$. 